\title{
Studies on the effect of Cold Plastic Deformation and Heat Treatment on the Microstructural Arrangement and Corrosion Behaviour of Mild Steel in Acidic Media
}

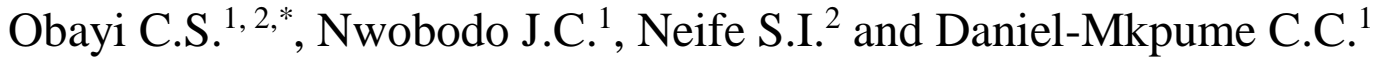 \\ ${ }^{1}$ Department of Metallurgical and Materials Engineering, University of Nigeria, Nsukka, Nigeria \\ ${ }^{2}$ Department of Mechanical and Mechatronic Engineering, Alex Ekwueme Federal University, Ndufu-Alike, \\ Ebonyi State, Nigeria \\ *Corresponding Author: camillus.obayi@unn.edu.ng
}

https://doi.org/10.36263/nijest.2019.02.0132

\begin{abstract}
Mild steel is the most extensively used carbon steel for numerous industrial applications, where it is exposed to various service environments containing acids, bases and salt solutions. From industrial point of view, plastic deformation and heat treatment are among the essential manufacturing steps in mild steel processing and these steps can implicate its corrosion behaviour. This work investigated the effect of cold plastic deformation and subsequent high temperature heat treatment on the microstructure and corrosion behaviour of mild steel in two different concentrations $(0.5 \mathrm{M}$ and 1.OM) of sulphuric acid $\left(\mathrm{H}_{2} \mathrm{SO}_{4}\right)$, using the weight loss method. Mild steel samples were cold pressed to thickness reduction of 20\%, 40\% and 50\% and subsequently heat treated at $700^{\circ} \mathrm{C}$ and $900^{\circ} \mathrm{C}$ and then air-cooled. The test duration lasted for 25 days and the weight loss measurements were taken at intervals of 5 days. It was observed that corrosion rates of the samples were generally higher in the 1.0M than in $0.5 \mathrm{M}$ acid solution. The as-received and heat-treated mild steel samples exhibited higher corrosion rates than the cold-pressed and heat-treated samples. The results indicated strongly that cold working accompanied by heat treatment improves corrosion resistance of mild steel in acidic media.
\end{abstract}

Keywords: Microstructure, corrosion behaviour, plastic deformation, heat treatment, mild steel, acidic media

\subsection{Introduction}

The study of corrosion of mild steel is of tremendous theoretical and practical concern due to its wide industrial applications and the need to prolong its life span in various service environments. Mild steel or low carbon steel is the most widely used carbon steel in various industries due to its availability, relative low cost, ease of fabrication, and adequate strength (Singh, et al., 2016; Zaafarany, 2013). For several years, mild steel in the form of plates and rods have found numerous applications as structural members in buildings, bridges, pipelines, ships, heavy vehicles and storage vessels (Osarolube, 1998; Clark and Varney, 1987). In these areas of application, mild steel is exposed to various service environments containing acids, bases and salt solutions, where it is prone to corrosion of the exposed surface. Mild steel has a major limitation of low corrosion resistance in various service environments containing acids and alkalis.

Furthermore, from manufacturing point of view, plastic deformation and heat treatment or thermomechanical processing are among the inherent and essential steps in fabrication of mild steel structures (Giuseppe, et al., 2009) and these steps further affect its corrosion behaviour in the service environments. Thermomechanical processing modifies microstructure and the microstructural 
parameters affected include grain size, grain shape, grain orientationand their distribution in the microstructure, which singly or collectively moderate dissolution kinetics (Obayi, et al., 2018).

Plastic deformation, especially cold plastic deformation improves strength at the expense of ductility; increasing residual stress and internal energy (Reza, et al., 2009). A cold-worked metal is also thermodynamically unstable and very reactive (Humphreys and Hatherly, 2004; Hodowany, et al., 2000). Heat treatment reduces strength and residual stress, restores ductility and moderates chemical reactivity. As a result, the corrosion behaviour of plastically deformed steels in various media especially in acidic media has been studied since the 1990s (Iofa, et al., 1968; El Din, et al., 1983; Shamseldin, et al., 1983; Foroulis and Uhlig, 1964; Finley and Meyers, 1970; Greene and Saltzman, 1964).

However, there is no consensus in the literature as to the effect of straining and heat treatment on corrosion of steel in various media. Straining has been considered to increase corrosion rate by (Foroulis and Uhlig, 1964; Finley and Meyers, 1970), while excessive straining slightly improved the corrosion resistance of steel according to (Shamseldin, et al., 1983). Similarly, cold work has been reported to affect the potential range of the passive region only (Finley and Meyers, 1970). The effect of deformation has also been reported to depend on prior heat treatment as well as the $\mathrm{pH}$ or concentration of the solution (Foroulis and Uhlig, 1964).

In view of differences in the information on the corrosion behaviour of steel in acid solutions, this work is targeted at re-examining the corrosion behaviour of mild steel in two different concentrations of sulphuric acid $\left(\mathrm{H}_{2} \mathrm{SO}_{4}\right)$ using mild steel cold deformed, heat treated at high temperatures and aircooled. Air cooling was chosen because mild steel is usually subjected to high temperatures and allowed to cool in air during construction or fabrication of mild steel structures.

\subsection{Materials and Methods}

\subsection{Materials}

The mild steel material in the form of plate of $5 \mathrm{~mm}$ thick was supplied by Auskan Co. Ltd, Kaduna State, Nigeria. The chemical composition of the mild steel determined via spectrometric analysis at Universal Steel, Ogba, Lagos State. is shown in Table 1. The corrosive media were $0.5 \mathrm{M} \mathrm{H}_{2} \mathrm{SO}_{4}$ and $1.0 \mathrm{M} \mathrm{H}_{2} \mathrm{SO}_{4}$. The solutions were prepared in the analytical laboratory of the Department of Pure and Applied Chemistry, University of Nigeria, Nsukka, Nigeria. Other materials were abrasive papers for grinding operations, glass beakers for containing the corrosive media, distilled water, and nylon threads for suspending the test specimens. The experimental setup was located at the Liquefied Natural gas (LNG) laboratory, University of Nigeria, Nsukka, Nigeria.

\subsection{Methods}

\subsubsection{Cold pressing, heat treatment and microstructural examination}

Specimens were cut from the $5 \mathrm{~mm}$-thick mild steel sheet and cold pressed to $20 \%$ (CP20\%), 40\% (CP40\%) and 50\% (CP50\%) thickness reduction to achieve $4.0 \mathrm{~mm}, 3.0 \mathrm{~mm}$ and $2.5 \mathrm{~mm}$ thicknesses, respectively, using pneumatic hammer (MASSEY; England), at the Nigerian Railway Corporation, Enugu.

The as-received and cold-pressed samples were heat-treated at $700^{\circ} \mathrm{C}$ and $900^{\circ} \mathrm{C}$ in a heat-treatment furnace (LABE 1210 Model, Delhi, India), soaked for one hour and air cooled. The samples were code named as follows: AR-700 and AR-900 for the as-received samples heat treated at $700^{\circ} \mathrm{C}$ and $900^{\circ} \mathrm{C}$, respectively; CP20\%-700, CP20\%C-900, CP40\%-700, CP40\%-900, CP50\%-700, and CP50\%-900 for the samples cold pressed to $20 \%, 40 \%$ and $50 \%$ reduction, heat treated at $700^{\circ} \mathrm{C}$ and $900^{\circ} \mathrm{C}$, respectively. 
The microstructure of the as-received mild steel, cold-pressed and heat-treated mild steel samples were examined using computerized metallurgical microscope equipped with digital camera and image analyser (Model mm39a00m, Labomed. Inc., USA). Prior to microstructural examination, the asreceived, cold-pressed and heat-treated samples were cut and mounted in acrylic resin and wet ground with 320-1000 grit $\mathrm{SiC}$ papers and finally polished with $6 \mu \mathrm{m}$ and $1 \mu \mathrm{m}$ diamond suspension and 0.05 $\mu \mathrm{m}$ alumina paste. They were then etched using a $2 \%$ Nital solution to expose the grains and grain boundaries. The average grain diameters on the surfaces of the as-received and deformed samples annealed at $700^{\circ} \mathrm{C}$ and $900^{\circ} \mathrm{C}$ were obtained using the image analyzer.

\subsubsection{Corrosion testing}

The corrosion behaviour of the as-received, cold-pressed and heat-treated mild steel samples was determined using weight loss or static immersion corrosion test method in two different concentrations of sulphuric acids $(0.5 \mathrm{M}$ and $1 \mathrm{M}$ solutions), prepared from $98 \%$ analytical grade concentrated sulphuric acid using distilled water.The weight-loss tests were performed following ASTM G31-72 standard.The mild steel samples were cut into test size of $5 \times 5 \times 5 \mathrm{~mm}^{3}$ for the asreceived or control sample and test sizes of $5 \times 5 \times 4 \mathrm{~mm}^{3}, 5 \times 5 \times 3 \mathrm{~mm}^{3}$ and $5 \times 5 \times 2.5 \mathrm{~mm}^{3}$ for $20 \%, 40 \%$ and $50 \%$ cold-pressed samples, respectively.

The cut samples were polished with $\mathrm{SiC}$ papers up to 1000 grit, and then cleaned with ethanol, dried and weighed. The weighed specimens were fully and separately immersed in $200 \mathrm{~mL} \mathrm{of} \mathrm{H}_{2} \mathrm{SO}_{4}$ solution for 25 days at room temperature. Three test specimens of each subset were taken out every 5 days, washed with distilled water, rinsed with ethanol, dried and re-weighed.The weight-loss corrosion test set up is shown in Figure 1.

The corrosion rate (CR) was determined based on the weight loss using Equation (1).

$$
C R=\frac{87.6 W}{d A t}
$$

Where $C R$ is the corrosion rate in millimetre per year $(\mathrm{mm} / \mathrm{yr}), W$ is the weight loss in grams $(\mathrm{g}), A$ is the exposed surface area $\left(\mathrm{cm}^{2}\right), t$ is the time of exposure in hours, and $\mathrm{d}$ is the density of the specimen $\left(7.85 \mathrm{~g} / \mathrm{cm}^{3}\right)$.

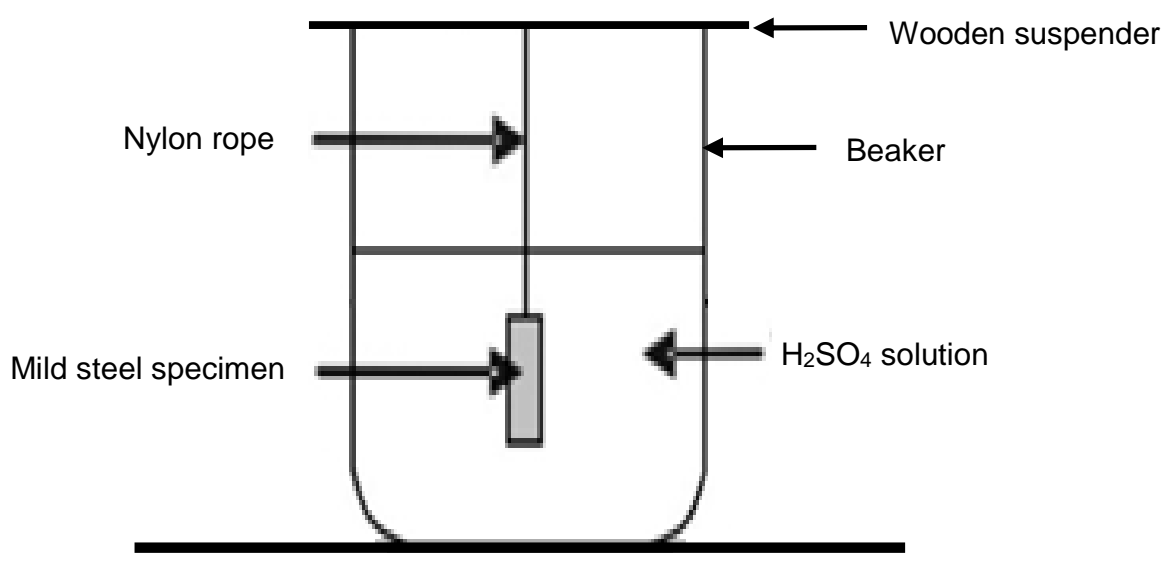

Figure 1: Weight-loss corrosion test set up 


\subsection{Results and Discussion}

\subsection{Chemical composition of the mild steel}

The chemical composition of the mild steel determined via spectrometric analysis is shown in Table 1.

Table 1: Chemical composition of the mild steel

\begin{tabular}{ccccccccc}
\hline Element & $\mathrm{C}$ & $\mathrm{Ni}$ & $\mathrm{Cr}$ & $\mathrm{Mn}$ & $\mathrm{Cu}$ & $\mathrm{Mo}$ & $\mathrm{S}$ & $\mathrm{P}$ \\
\hline Weight $\%$ & 0.1420 & 0.0410 & 0.0800 & 0.7090 & 0.0850 & 0.0001 & 0.0300 & 0.0300 \\
\hline Element & $\mathrm{Si}$ & $\mathrm{Al}$ & $\mathrm{Nb}$ & $\mathrm{B}$ & $\mathrm{Ti}$ & $\mathrm{W}$ & $\mathrm{V}$ & $\mathrm{Fe}$ \\
\hline Weight $\%$ & 0.2500 & 0.0080 & 0.0001 & 0.0001 & 0.0090 & 0.0001 & 0.0001 & balance \\
\hline
\end{tabular}

\subsection{Microstructure of the as-received, cold-pressed and heat-treated mild steel samples}

Figure 2 (a-1) shows microstructural evolution of the as-received, cold-pressed and heat treated mild steel samples, while Table 2 shows the average grain diametres of as-received and deformed samples annealed at $700^{\circ} \mathrm{C}$ and $900^{\circ} \mathrm{C}$. The increase in average grain diametre as the heat treatment temperature increased can be observed in Figure 2 and in Table 2. The grain size evolution was also dependent on the degree of cold pressing and the higher the degree of cold pressing, the smaller the grain size. The as-received has the biggest grain size while the cold-pressed to 50\% reduction has the smallest grain size at the heat treatment temperatures. The microstructure was considered in an attempt to correlate the corrosion behaviour with microstructural evolution.

Table 2: Average grain sizes for some of the mild steel samples

\begin{tabular}{|c|c|c|c|c|c|c|c|c|c|}
\hline Materials code & $\mathrm{AR}$ & AR-700 & AR-900 & СР20\%-700 & CP20\%-900 & CP $40 \%-700$ & CP40\%-900 & CР50\%-700 & CP50\%-700 \\
\hline $\begin{array}{l}\text { Average grain } \\
\text { size }(\mu \mathrm{m})\end{array}$ & $30.2 \pm 3.3$ & $37.1 \pm 2.5$ & $49.1 \pm 2.2$ & $32.1 \pm 2.2$ & $38.8 \pm 3.9$ & $24.2 \pm 1.8$ & $29.6 \pm 3.2$ & $21.4 \pm 2.7$ & $26.8 \pm 1.9$ \\
\hline
\end{tabular}

Heat treatment of the as-received mild steel at $700^{\circ} \mathrm{C}$ and $900^{\circ} \mathrm{C}$ resulted in an increase in grain diameter as can be seen in Figure 1. The as-received grain structure was also diffuse at $900^{\circ} \mathrm{C}$ and was accompanied by initiation of carbide precipitation at the grain boundaries. For the as-cold pressed and heat-treated mild steel samples, the grain diameters were smaller than that of the as-received at the heat treatment temperatures. The grain size varied with the degree of cold work and heat treatment temperatures. The higher the degree of cold work, the smaller the grain size at each heat treatment temperature. This phenomenon might be attributed to the following reasons: An average grain size obtained after heat treatment is a function of prior strain (Priestner and Ibraheem, 2000). The amount of strain determines the rates of nucleation and subsequent grain growth of the recrystallized grains in a deformed state (Humphreys and Hatherly, 2004). Cold plastic deformation hastens grain subdivision due to the relatively higher dislocation density and substantial microstructural inhomogeneities introduced during deformation (Song, et al., 2006). The higher the degree of cold work, the higher the nucleation rate and the smaller the final recrystallized grain size (Humphreys and Hatherly, 2004; Anthonione, et al., 1977). That is why the mild steel sample cold pressed to the highest degree (50\%) has the smallest grain size. 


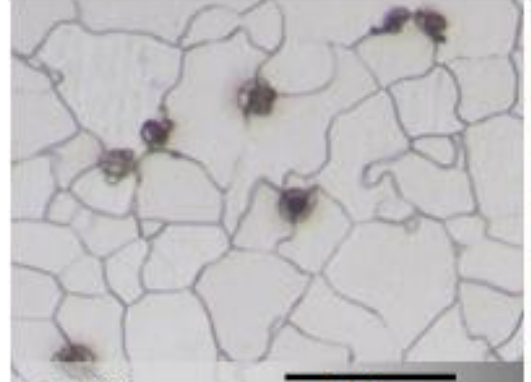

(a) AR

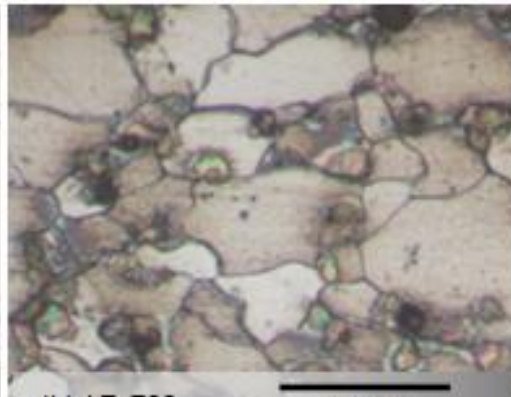

(b) AR-700
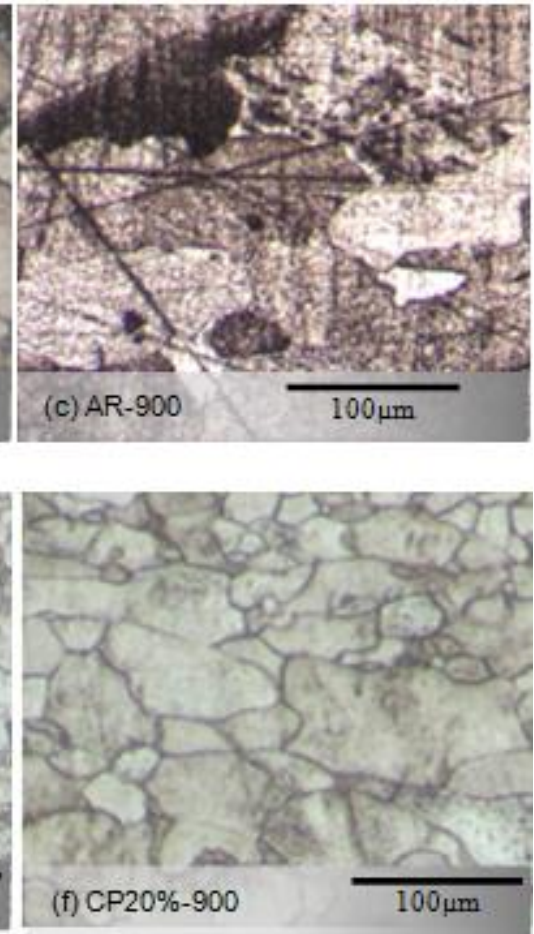
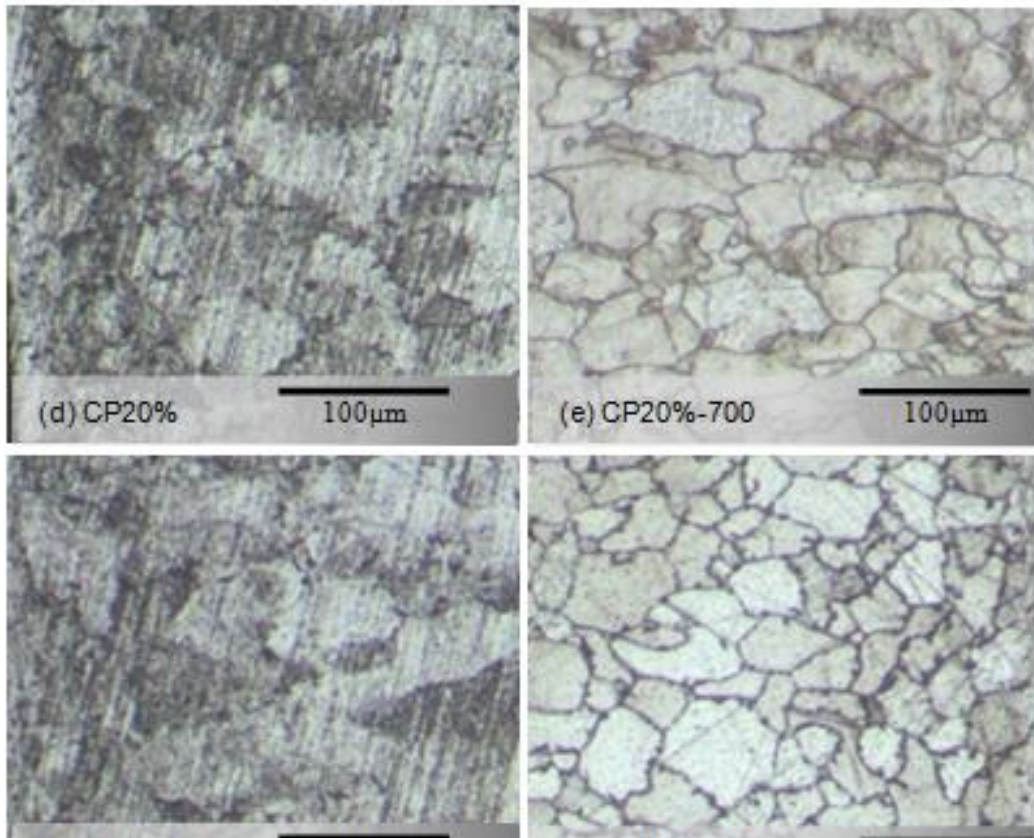

(g) $\mathrm{CP} 40 \%$

$100 \mu \mathrm{m}$

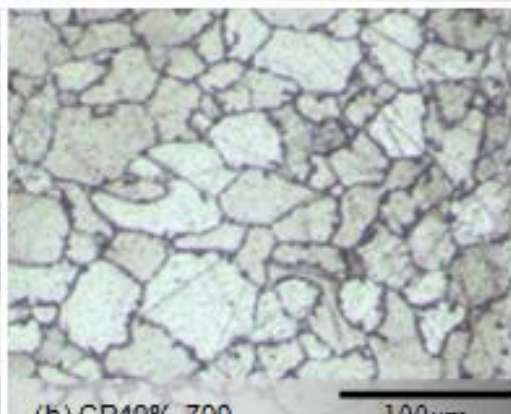

(h) $\mathrm{CP} 40 \%-700$

$100 \mu \mathrm{m}$
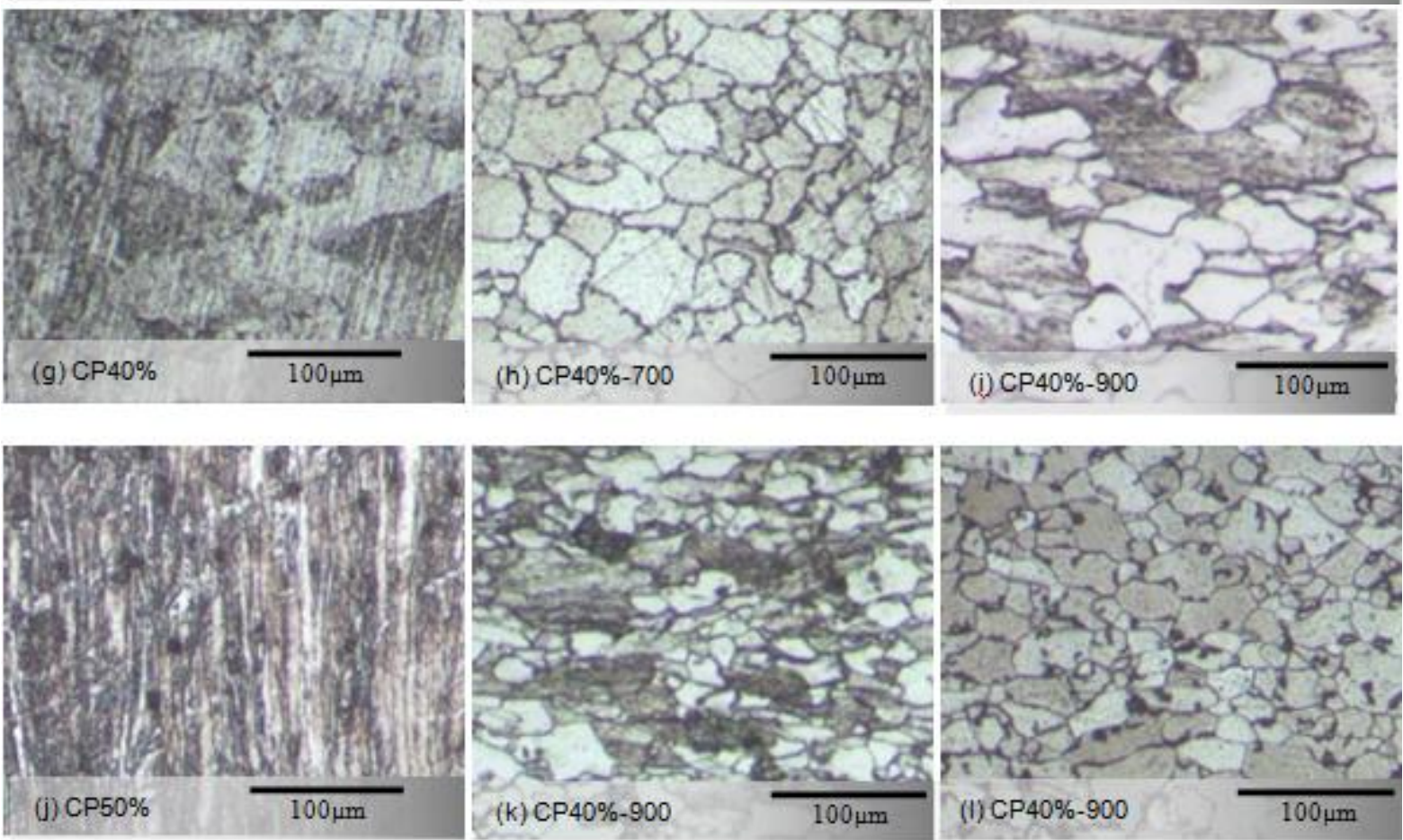

Figure 2: Microstructure of the as-received and cold-pressed mild steel samples heat treated at $700^{\circ} \mathrm{C}$ and $900^{\circ} \mathrm{C}$.

\subsection{Corrosion behaviour of as-received, cold pressed and heat-treated mild steel samples}

Figures 3 and 4 are plots of weight loss and corrosion rate against corrosion test duration for the asreceived mild steel and cold pressed mild steel samples heat treated at $700^{\circ} \mathrm{C}$ and immersed in $0.5 \mathrm{M}$ $\mathrm{H}_{2} \mathrm{SO}_{4}$ solution, respectively. Figures 5 and 6 show the weight loss and corrosion rate versus corrosion test duration for the same set of samples heat treated at $900^{\circ} \mathrm{C}$ and immersed in $0.5 \mathrm{M} \mathrm{H}_{2} \mathrm{SO}_{4}$ solution. These sets of samples heat treated at $700^{\circ} \mathrm{C}, 900^{\circ} \mathrm{C}$ and immersed in $0.5 \mathrm{M} \mathrm{H}_{2} \mathrm{SO}_{4}$ solution exhibited similar corrosion behaviour. The maximum weight losses and corrosion rates of the samples occurred on the $5^{\text {th }}$ day. However, the as-received mild steel (AR) has the highest weight loss and corrosion rate while the cold-pressed mild steel to 50\% (CP50\%) degree has the lowest weight loss and corrosion rate. The weight losses and corrosion rates of the mild steel samples cold pressed to $20 \%(\mathrm{CP} 20 \%)$ and $40 \%(\mathrm{CP} 40 \%)$ reduction lie between that of AR and (CP50\%). It can also be 
observed in Figures 4 and 6 that corrosion rates of all the samples immersed in $0.5 \mathrm{M} \mathrm{H}_{2} \mathrm{SO}_{4}$ solution consistently decreased after the $5^{\text {th }}$ day to the $25^{\text {th }}$ day.

The weight loss and corrosion rate against corrosion test duration for the as-received mild steel and cold pressed mild steel samples heat treated at $700^{\circ} \mathrm{C}$ and immersed in $1.0 \mathrm{M} \mathrm{H}_{2} \mathrm{SO}_{4}$ solution are shown in Figures 7 and 8 while Figures 9and 10 show the weight loss and corrosion rate against corrosion test duration for the as-received mild steel and cold pressed mild steel samples heat treated at $900^{\circ} \mathrm{C}$ and immersed $1.0 \mathrm{M} \mathrm{H}_{2} \mathrm{SO}_{4}$ solution. These sets of samples immersed in $1.0 \mathrm{M} \mathrm{H}_{2} \mathrm{SO}_{4}$ solution exhibited similar corrosion behaviour to those immersed in $0.5 \mathrm{M} \mathrm{H}_{2} \mathrm{SO}_{4}$ solution. However, weight losses and corrosion rates were higher in $1.0 \mathrm{M} \mathrm{H}_{2} \mathrm{SO}_{4}$ solution than in $0.5 \mathrm{M} \mathrm{H}_{2} \mathrm{SO}_{4}$ solution. It is also noteworthy that the corrosion behaviour of the samples appears to be grain dependent as the asreceived mild steel having the biggest grain size has the highest corrosion rate while the $50 \%$ coldpressed sample which has the smallest grain size has the least corrosion rate in both acidic concentrations.

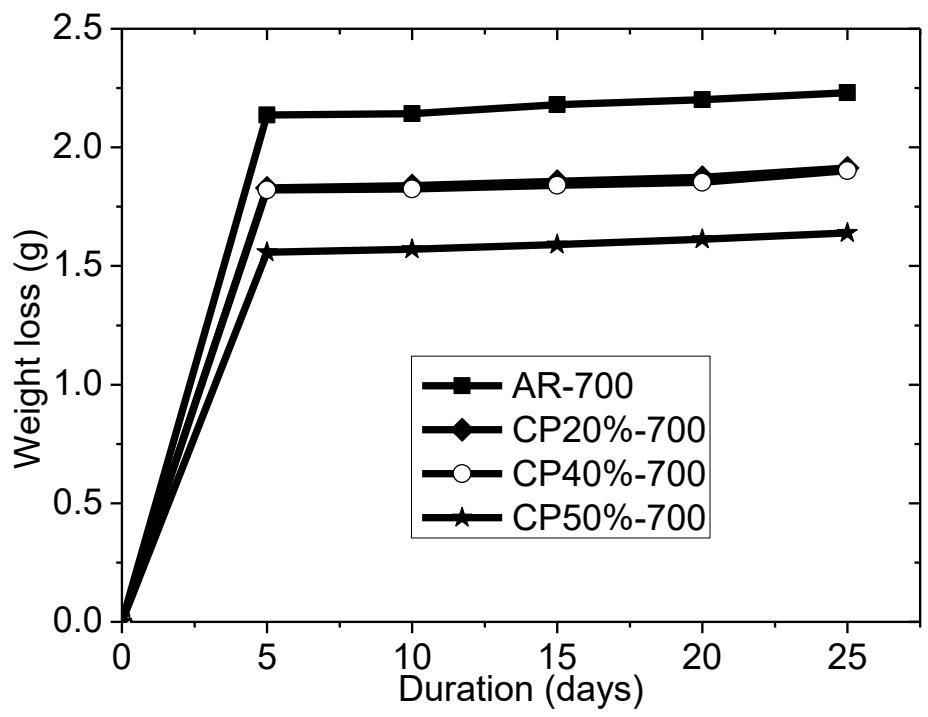

Figure 3: Weight loss vs corrosion test duration for the mild steel samples heat treated at $700^{\circ} \mathrm{C}$ and immersed in $0.5 \mathrm{M} \mathrm{H}_{2} \mathrm{SO}_{4}$ solution.

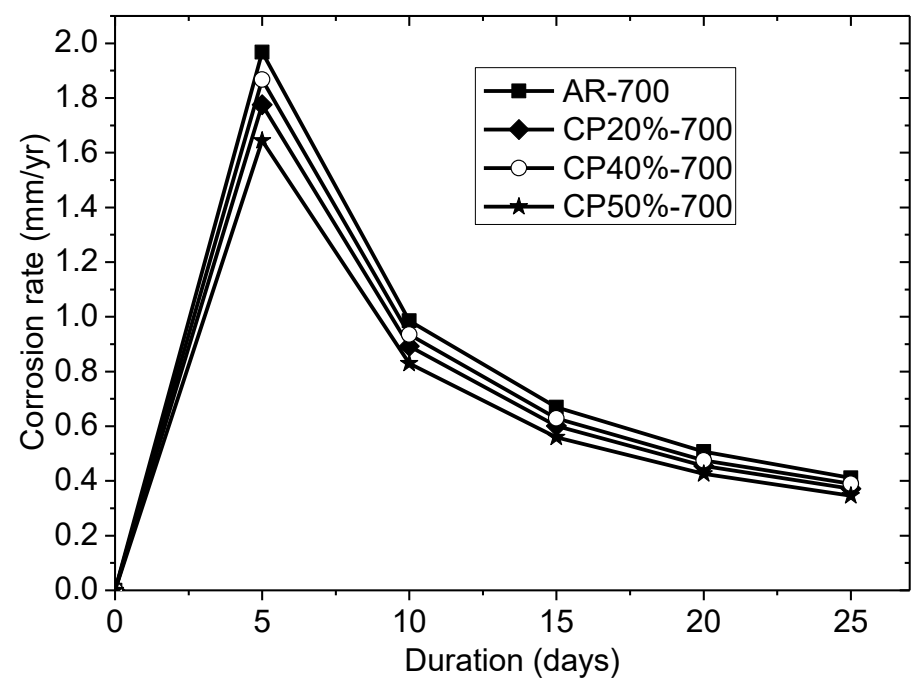

Figure 4: Corrosion rate vs corrosion test duration for the mild steel samples heat treated at $700^{\circ} \mathrm{C}$ and immersed in $0.5 \mathrm{M} \mathrm{H}_{2} \mathrm{SO}_{4}$ solution. 


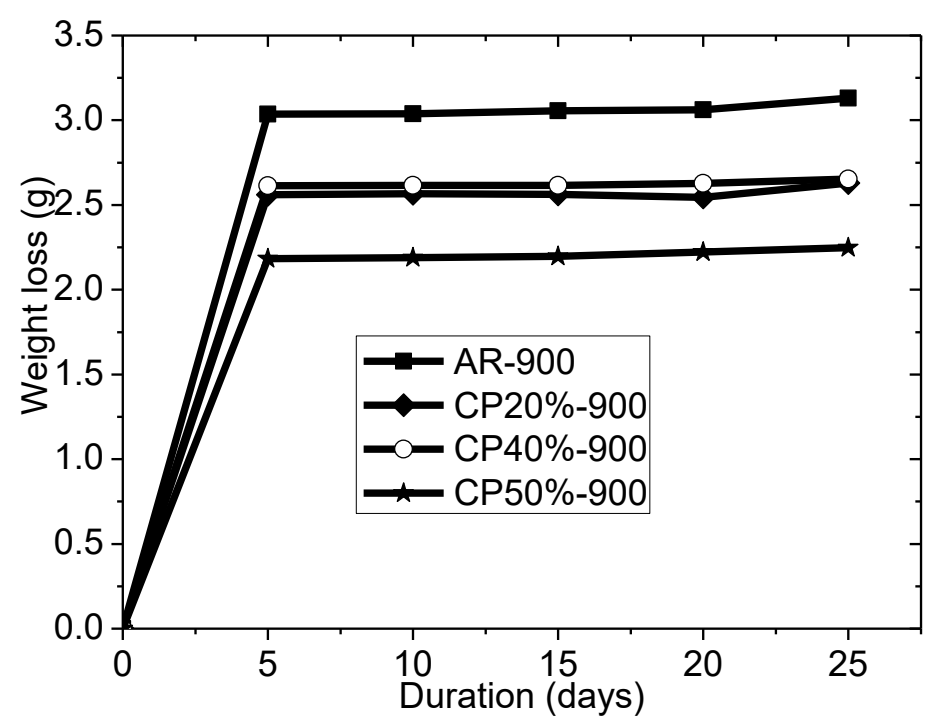

Figure 5: Weight loss vs corrosion test duration for the mild steel samples heat treated at $900^{\circ} \mathrm{C}$ and immersed in $0.5 \mathrm{M} \mathrm{H}_{2} \mathrm{SO}_{4}$ solution.

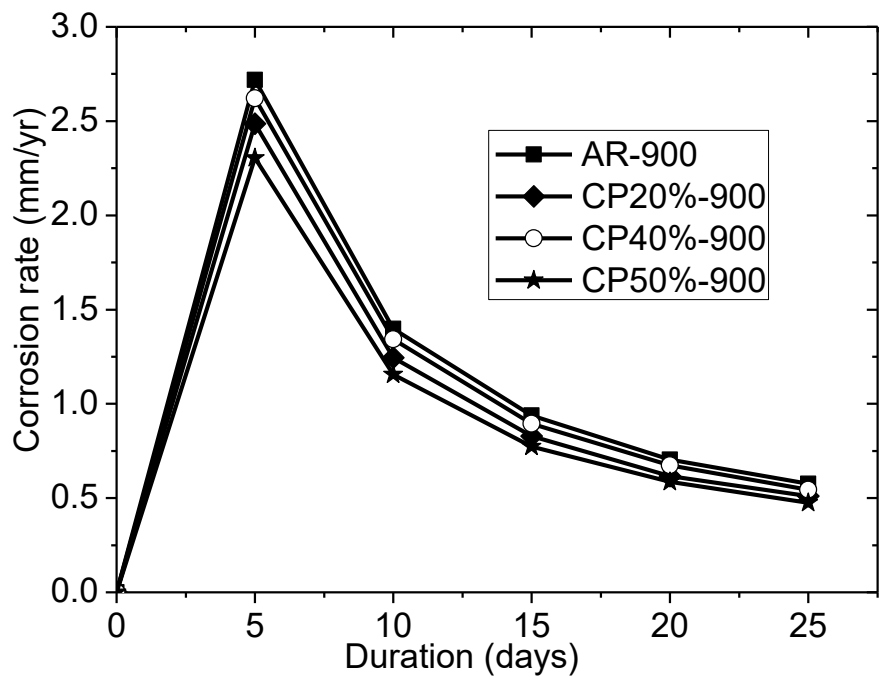

Figure 6: Corrosion rate vs corrosion test duration for the mild steel samples heat treated at $900^{\circ} \mathrm{C}$ and immersed in $0.5 \mathrm{M} \mathrm{H}_{2} \mathrm{SO}_{4}$ solution.

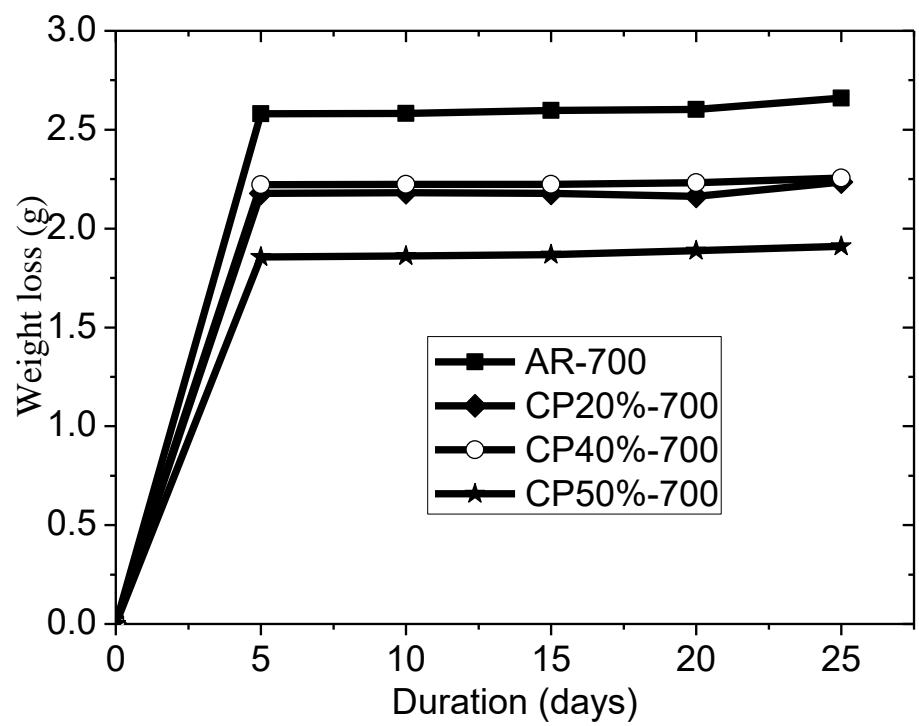

Figure 7: Corrosion rate vs corrosion test duration for the mild steel samples heat treated at $700^{\circ} \mathrm{C}$ and immersed in $1.0 \mathrm{M} \mathrm{H}_{2} \mathrm{SO}_{4}$ solution. 


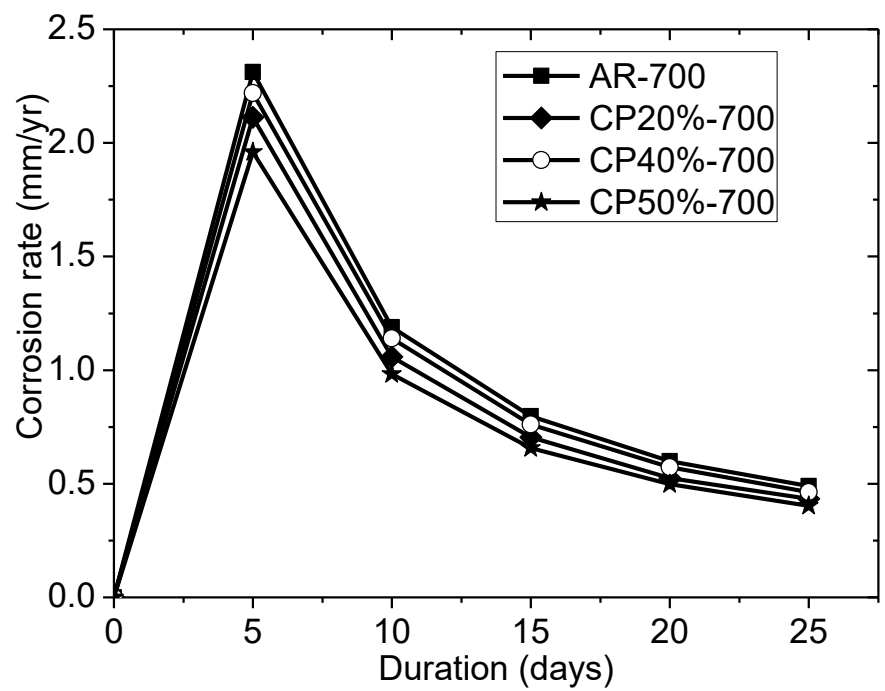

Figure 8: Corrosion rate vs corrosion test duration for the mild steel samples heat treated at $700^{\circ} \mathrm{C}$ and immersed in $1.0 \mathrm{M} \mathrm{H}_{2} \mathrm{SO}_{4}$ solution.

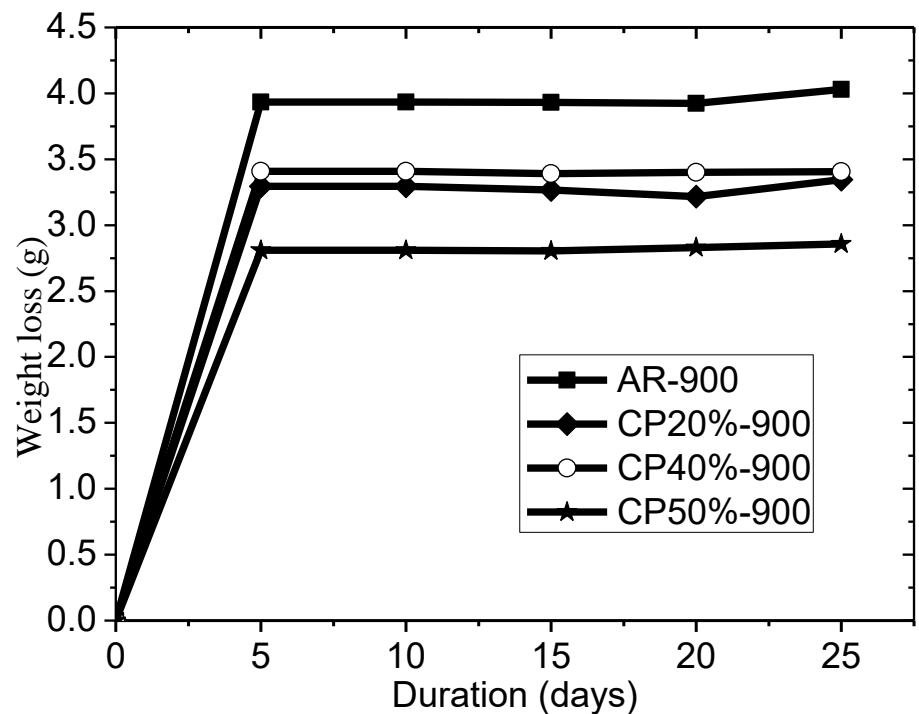

Figure 9: Weight loss vs corrosion test duration for the mild steel samples heat treated at $900^{\circ} \mathrm{C}$ and immersed in $1.0 \mathrm{M} \mathrm{H}_{2} \mathrm{SO}_{4}$ solution.

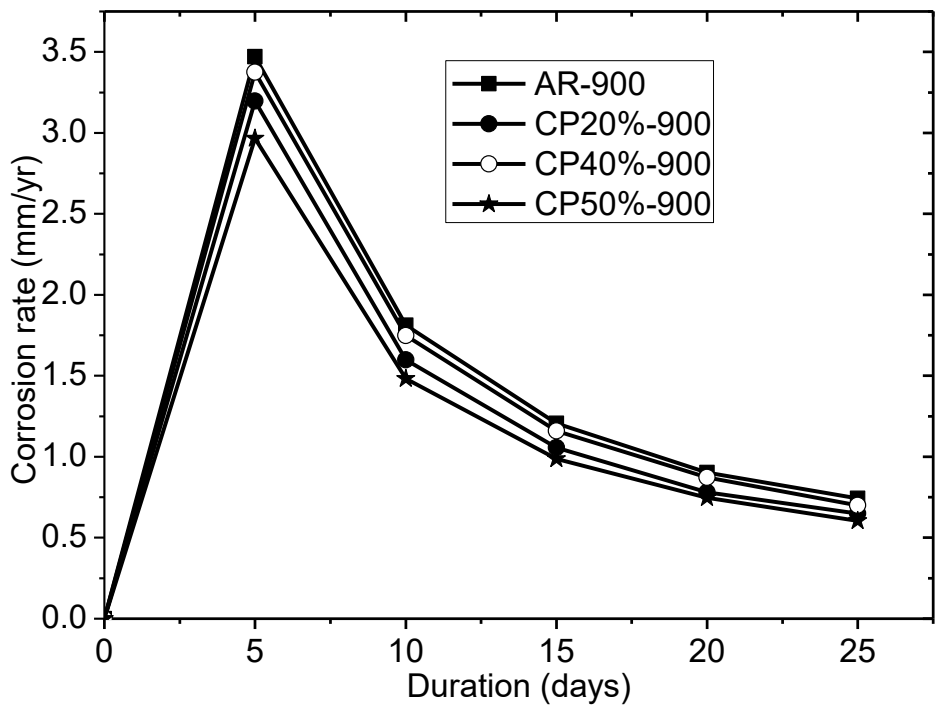

Figure 10: Corrosion rate vs corrosion test duration for the mild steel samples heat treated at $900^{\circ} \mathrm{C}$ and immersed in $1.0 \mathrm{M} \mathrm{H}_{2} \mathrm{SO}_{4}$ solution. 
Generally, the weight losses and corrosion rates of as-received, cold pressed and heat-treated mild steel samples were higher in $1.0 \mathrm{M} \mathrm{H}_{2} \mathrm{SO}_{4}$ than in $0.5 \mathrm{M} \mathrm{H}_{2} \mathrm{SO}_{4}$ solutions. This is expected and is in agreement with the work of (Noor and Al-Moubaraki, 2008) who found out that the corrosion rates of mild steel increase with the increase in acid concentration.

The weight losses and corrosion rates of cold pressed and heat-treated mild steel samples are also generally lower in both $0.5 \mathrm{M} \mathrm{H}_{2} \mathrm{SO}_{4}$ and $1.0 \mathrm{M} \mathrm{H}_{2} \mathrm{SO}_{4}$ solutions than the as-received and heat-treated mild steel. This result suggests that cold work followed by heat treatment at high temperatures reduces dissolution rate in acid solution. Extreme cold work has been suggested to slightly improve the corrosion resistance of steel (Shamseldin et al., 1983). This result could be explained by considering that cold work followed by heat treatment refines microstructure and finer grain drives passivation kinetics or oxide formation (Ralston, et al., 2010) and enables the formation of more compact and stable passive films or oxides on the corroding surface (Ralston and Birbilis, 2010). The compact oxide films impede further dissolution of the cold pressed and annealed samples, especially the (CP50\%) that possessed smaller grain structure as can be seen in Figure 2.

The corrosion rates of all the samples in both $0.5 \mathrm{M} \mathrm{H}_{2} \mathrm{SO}_{4}$ and $1.0 \mathrm{M} \mathrm{H}_{2} \mathrm{SO}_{4}$ solutions consistently decreased after the $5^{\text {th }}$ day to the $25^{\text {th }}$ day. This could be attributed to the initial aggressive effect of the acid on the surface of the mild steel specimens for the first five days, which decreased afterwards due to the formation of iron oxide $(\mathrm{FeO})$ and accumulation of corrosion products, which somewhat impeded further dissolution of the samples in the acid solutions.

The as-received and heat-treated mild steel had the highest weight loss and corrosion rate among other samples. This could be attributed to the fact that the heat treatment of low carbon steel at temperatures greater $850^{\circ} \mathrm{Cleads}$ to carbide precipitation along grain boundaries, thereby forming active galvanic cells and increasing anodic dissolution (El Din, et al., 1983; Shamseldin, et al., 1983).This could also be due to poor adsorption of oxides on the mild steel surface according (Iofa, et al., 1968) who has confirmed that annealing iron at higher temperatures $\left(\geq 750^{\circ} \mathrm{C}\right)$ makes it less corrosion resistant due to reduced adsorption of passive oxides. Since nucleation and growth of oxide films on metals that exhibit some level of passivity increase with decrease in grain size (Ralston, et al., 2010), it follows that as-received and heat-treated mild steel which has bigger grain size than other samples would be less corrosion resistant due to poor oxide film adsorption on the surface.

\subsection{Conclusion}

The effect of cold plastic deformation and heat treatment on the microstructure and corrosion behaviour of mild steel in two molar concentrations $(0.5 \mathrm{M}$ and $1.0 \mathrm{M})$ of sulphuric acid $\left(\mathrm{H}_{2} \mathrm{SO}_{4}\right)$ solutions, using the weight loss method has been investigated. The key results of this investigation are as follows:

i. Heat treatment of the as-received and cold pressed mild steel specimens at $700^{\circ} \mathrm{C}$ and $900^{\circ} \mathrm{C}$ modified their microstructures and resulted in an increase in their grain diameters, but grain diameter of the as-received was bigger than that of the cold-pressed samples at the heat treatment temperatures.

ii. As expected, the corrosion rates of the samples were generally higher in the $1.0 \mathrm{M}$ than in $0.5 \mathrm{M}$ acid solution because corrosion rates of mild steel increase with the increase in acid concentration.

iii. The corrosion rates of all the samples in both $0.5 \mathrm{M} \mathrm{H}_{2} \mathrm{SO}_{4}$ and $1.0 \mathrm{M} \mathrm{H}_{2} \mathrm{SO}_{4}$ solutions consistently decreased from the $5^{\text {th }}$ day to the $25^{\text {th }}$ day, showing clearly that there was some level of oxide formation or passivation which impeded further dissolution of the samples in the acid solutions. 
iv. Noteworthy is the fact that the corrosion rates of cold pressed and heat-treated mild steel samples were generally lower in both $0.5 \mathrm{M} \mathrm{H}_{2} \mathrm{SO}_{4}$ and $1.0 \mathrm{M} \mathrm{H}_{2} \mathrm{SO}_{4}$ solutions than that of the as-received and heat-treated mild steel sample. The result indicated strongly that cold work followed with annealing heat treatment improves corrosion resistance of mild steel in acidic media.

v. Corrosion rates of the samples appeared to be grain size dependent as the as-received and heattreated mild steel which had the biggest grain size had the highest corrosion rate, while the sample cold pressed to 50\% (CP50\%) and heat-treated had the smallest grain size and was the most corrosion resistant.

\section{References}

Abbaschian R., Abbaschian L., Reed-Hill R.E., (2009). Physical metallurgy principles (4 ${ }^{\text {th }}$ ed.), CENAGE Learning, Australia.

Anthonione C., Marino F., Riontino G., Tabasso M.C., (1977). Effect of slight deformations on grain growth in iron. Journal of Materials Science, 12, PP. 747-750.

Clark D.S. and Varney W.R. (1987). Physical metallurgy for engineers. Van Nostrand Reinhold Ltd., Canada.

El Din, A.S., El Kader, J.A., El Wahab, F.A., Hegazy, H., (1983). Effect of cold work on anodic polarization of low carbon steel. Journal of Materials science, 18, pp. 2732-2742.

Finley, T.C. and Meyers, J.R., (1970). Effect of cold work on anodic polarization of Fe in sulphuric acid. Corrosion, 26(4), pp. 150-152.

Foroulis, Z.A.; Uhlig, H.H., (1964). Effect of cold-work on corrosion of iron and steel in hydrochloric acid. Journal of the Electrochemical Society, 111(5), pp. 522-528.

Giuseppe P.P.A., De Camargo B., Marcelo A. F., (2009). Plastic deformation analysis of low carbon steel due to metal hole punching using coated and uncoated tools. Journal of Brazil Society of Mechanical Science \& Engineering, 3I (1), pp. 52 - 56.

Greene N. and Saltzman G., (1964). Effect of plastic deformation on the corrosion of Iron and steel. Corrosion, 20, pp. 293t - 298t.

Hodowany, J., et al., (2000). Partition of plastic work into heat and stored energy in metals. Experimental Mechanics, 40(2), p. 113-123.

Humphreys, F.J. and Hatherly, M., (2004). Recrystallization and related annealing phenomena ( $2^{\text {nd }}$ ed.). ELSVIER, United Kingdom.

Iofa Z., Batrakov, V., Nikiforova, Y.A., (1968). On the influence of deformation and heat treatment of Fe on adsorption and action of corrosion inhibitors. Corrosion Science, 8, pp. 573-582.

Noor, E. A. Al-Moubaraki A. H., (2008). Corrosion behaviour of mild steel in hydrochloric acid solutions, International Journal of Electrochemical Science, 3, pp. 806-818.

Obayi C.S., Nnamchi P.S., Tolouel R., Okorie B.A., Mantovani D., (2018). Crystallographic texturedependent dissolution of thermomechanically processed biodegradable pure iron, Journal of Metallurgy \& Materials Engineering, 11(1), pp. 77-86.

Osarolube E., (1998). Effect of prior cold reduction on the properties of heat treated low carbon steel. Nigerian Journal of Physics, 10, pp. 133-136.

Priestner R. and Ibraheem A.K., (2000). Processing of steel for ultrafine ferrite grain structures. Materials Science. Technology, 16 pp. 1267-1272. 
Ralston K. and Birbilis N., (2010). Effect of grain size on corrosion: a review. Corrosion, 66, pp. 075005-075013.

Ralston K., Birbilis N., Davies C., (2010). Revealing the relationship between grain size and corrosion rate of metals. Scripta Mater, 63, pp. 1201-1204.

Shamseldin, A.M., ABD Elkader, J.M., ABD EL Wahab, F.M., Hegazy, H.S., (1983). Effect of cold work on anodic polarization of low carbon steel. Journal of Materials Science, 18, pp. $2732-2742$.

Singh, D.K., Kumar S., Dayabhanu G.U., John R.P., (2016). 4(N,Ndimethylamino)benzaldehyde nicotinic hydrazone as corrosion inhibitor for mild steel in $1 \mathrm{M} \mathrm{HCl}$ solution: An experimental and theoretical study. Journal of Molecular Liquids, 216, pp. 738-746.

Song, R., Ponge, D., Raabe, D., Speer, J.G., Matlock, D.K., (2006). Overview of processing, microstructure and mechanical properties of ultrafine grained bcc steels. Materials Science and Engineering A, 441, pp. 1-17.

Zaafarany I.A., (2013). Corrosion inhibition of mild steel in hydrochloric acid solution using cationic surfactant olyel-amido derivatives. International Journal of Electrochemical Science, 8, pp. 95319542.

\section{Cite this article as:}

Obayi C.S., Nwobodo J.C., Neife S.I. and Daniel-Mkpume C.C., 2019. Studies on the effect of Cold Plastic Deformation and Heat Treatment on the Microstructural Arrangement and Corrosion Behaviour of Mild Steel in Acidic Media. Nigerian Journal of Environmental Sciences and Technology, 3(2), pp. 331-341. https://doi.org/10.36263/nijest.2019.02.0132 